\title{
Early stage hydration properties of calcium aluminosilicate slag
}

\author{
Y.Y. ZHANG \\ College of Material Science and Engineering, Chongqing University, Chongqing 400030, P. R. China \\ Y.H. QI
}

State Key Laboratory of Advance Steel Processes and Products, Central Iron and Steel Research Institute, Beijing 100081, China

Z.S. ZOU

School of Material and Metallurgy, Northeast University, Shenyang 110819, China

\begin{abstract}
KEYWORD: Calcium aluminosilicate slag; High ferrous bauxite; Hydration properties
ABSTRACT: The calcium aluminosilicate slag cement clinker was prepared from bauxite-coal composite pellets by high temperature reduction and smelting process. The hydration results show that, after hydration for 28 days, the hydration products of calcium aluminosilicate slag are mainly composed of killalaite $(\mathrm{Ca} 3.2(\mathrm{H} 0.6 \mathrm{Si2O} 7)(\mathrm{OH}))$, calcium silicate hydrate $(\mathrm{Ca} 1.5 \mathrm{SiO} 3.5 \cdot \mathrm{xH} 2 \mathrm{O})$ and calcium aluminates

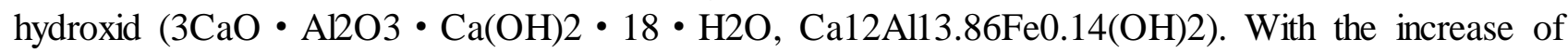
$\mathrm{w}(\mathrm{CaO}) / \mathrm{w}(\mathrm{SiO} 2)$ ratio, the killalaite disappeared, the $3 \mathrm{CaO} \cdot \mathrm{Al} 2 \mathrm{O} 3 \cdot \mathrm{Ca}(\mathrm{OH}) 2 \cdot 18 \cdot \mathrm{H} 2 \mathrm{O}$ and Ca12Al13.86Fe0.14(OH)2 amounts were increased gradually as a function of $\mathrm{w}(\mathrm{CaO}) / \mathrm{w}(\mathrm{SiO} 2)$ ratio. The $\mathrm{C} 3 \mathrm{~A}$ and $\mathrm{C} 12 \mathrm{~A} 7$ have very exothermic hydration characteristic and faster hydration rate, promoted the hydration activity of $\beta-\mathrm{C} 2 \mathrm{~S}$. The calcium aluminosilicate slag cement clinker has a higher reactivity during the early stage of the hydration process.
\end{abstract}

\section{INTRODUCTION}

Type area

In China, more than 0.5 billion tons of high ferrous bauxite has been explored in the last 20 years (Liu et al. 2012, Wang et al. 2011 \& Wang et al. 2010). These high ferrous bauxite is mainly composed of gibbsite $\left(\mathrm{Al}(\mathrm{OH})_{3}\right)$, diaspore $(\mathrm{AlOOH})$, goethite $(\mathrm{FeOOH})$, hematite $\left(\mathrm{Fe}_{2} \mathrm{O}_{3}\right)$ and kaolinite $\left(\mathrm{Al}_{2} \mathrm{Si}_{2} \mathrm{O}_{5}(\mathrm{OH}) 4 \cdot 2 \mathrm{H}_{2} \mathrm{O}\right)$, the content of $\mathrm{Al}_{2} \mathrm{O}_{3}$ and $\mathrm{Fe}_{2} \mathrm{O}_{3}$ is over $65 \mathrm{wt} \%$, the content of $\mathrm{SiO}_{2}$ is about 712wt\% (Liu et al. $2010 \&$ Zhang et al. 2014). Current studies estimate that the coal-based direct reduction method can be used to produce a high quality pig iron from low grade iron ores, and thus it is an ideal technology for adding value to marginal iron ore reserves (Kapure et al. 2011 \& Guo et al. 2013). Valuable iron in high ferrous bauxite is preferentially recovered by coal-based direct reduction and melting method (Zhang et al. 2015a). But the residual solid wastes, called calcium aluminosilicate slag, are still discarded as waste in large quantities. However, these calcium aluminosilicate slag with higher $\mathrm{Al}_{2} \mathrm{O}_{3}(28-30 \%)$ and $\mathrm{CaO}(45-55 \%)$ content has not been utilized effectively in China. These starting materials lead to a final clinker based on the ternary system $\mathrm{CaO}-\mathrm{SiO}_{2}-\mathrm{Al}_{2} \mathrm{O}_{3}$ and are formed by three main minerals: $\mathrm{C}_{2} \mathrm{~S}$ (dicalcium silicate), $\mathrm{C}_{12} \mathrm{~A}_{7}$ (mayenite) and $\mathrm{C}_{2} \mathrm{AS}$ (gehlenite), other minor phases such as $\mathrm{C}_{3} \mathrm{~A}$ (tricalcium aluminate), $\mathrm{CA}$ (monocalcium aluminate), $\mathrm{CA}_{2}$ (calcium dialuminate) can also be present (Zhang et al. 2015b).

Conventionally, calcium aluminate cement is produced by fusing limestone as a source of calcium oxide $(\mathrm{CaO})$ and bauxite as a source of aluminium oxide $\left(\mathrm{Al}_{2} \mathrm{O}_{3}\right)$ at high temperatures up to $1400^{\circ} \mathrm{C}$ (Zawrah et al.2011 \& David et al. 2013). The chemical composition of calcium aluminate cement may vary over wide range of $\mathrm{Al}_{2} \mathrm{O}_{3}$ contents ranging between about $40 \%$ and $80 \%$ (Zawrah et al. 2011). The principal reactive phase is $\mathrm{CA}$ and it is responsible for properties of material. Other mineralogical phases appear in minor amounts and $\mathrm{C}_{2} \mathrm{~S}$ (belite), $\mathrm{C}_{2} \mathrm{AS}$ (gehlenite), and ferrite solid solutions, meanwhile the calcium aluminate 
cements contain phases such as $\mathrm{C}_{12} \mathrm{~A}_{7}, \mathrm{CA}, \mathrm{C}_{3} \mathrm{~A}$ and $\mathrm{CA}_{2}$ (Touzo et al. 2001 \& Bensted et al, 2002). The $\mathrm{C}_{12} \mathrm{~A}_{7}$ forms thermodynamically metastable hydrates, such as $\mathrm{C}_{2} \mathrm{AH}_{8}, \mathrm{C}_{4} \mathrm{AH}_{19}, \mathrm{CAH}_{10}$ etc. at an early hydration time, and then these metastable hydrates convert to thermodynamically stable hydrates such as, $\mathrm{C}_{3} \mathrm{AH}_{6}, \mathrm{AH}_{3}$ etc (Zhen et al. 2012, Luz et al, 2011 and Pacewska et al. 2013).

It can be seen that the calcium aluminosilicate slag is a kind of clinker which between Portland cement and calcium aluminate cement, has the very high research value. However, as thus to date there have been no comprehensive studies in the pertinent literature on how the calcium aluminosilicate slag systems function.

In this paper, the calcium aluminosilicate slag were synthesized by high temperature reduction and smelting process. The phase composition, microstructure and physical chemical properties of calcium aluminosilicate slag are detected by X-ray diffraction analysis (XRD), scanning electron microscopy (SEM) and energy dispersive microanalysis (EDS). The early hydration mechanical and microstructural properties of calcium aluminosilicate slag were also investigated.

\section{MATERIALS AND METHODS}

\section{Synthesis of the calcium aluminosilicate slag}

The bauxite powders were thoroughly mixed with anthracite, slaked lime $\left(\mathrm{Ca}(\mathrm{OH})_{2}\right)$ and fluorite $\left(\mathrm{CaF}_{2}\right)$ at different $w(\mathrm{CaO}) / w\left(\mathrm{SiO}_{2}\right)$ ratios and the mixtures were put into a roller press to compact and produce bauxite-coal composite pellets. Then the bauxite-coal composite pellets were dried at $150{ }^{\circ} \mathrm{C}$ for 200 min in a Muffle furnace. After finishing the dried process the bauxite-coal composite pellets were put into a corundum crucible and reduced in a tube furnace at required temperature under $\mathrm{N}_{2}$ flow rate of $1.5 \mathrm{~L} / \mathrm{min}$. After reduction and smelting, the iron nuggets and calcium aluminosilicate slag were magnetic separating. The iron nuggets were used to steel production and calcium aluminosilicate slag was used to produce Portland cement, the whole flow sheet is shown in Fig.1.

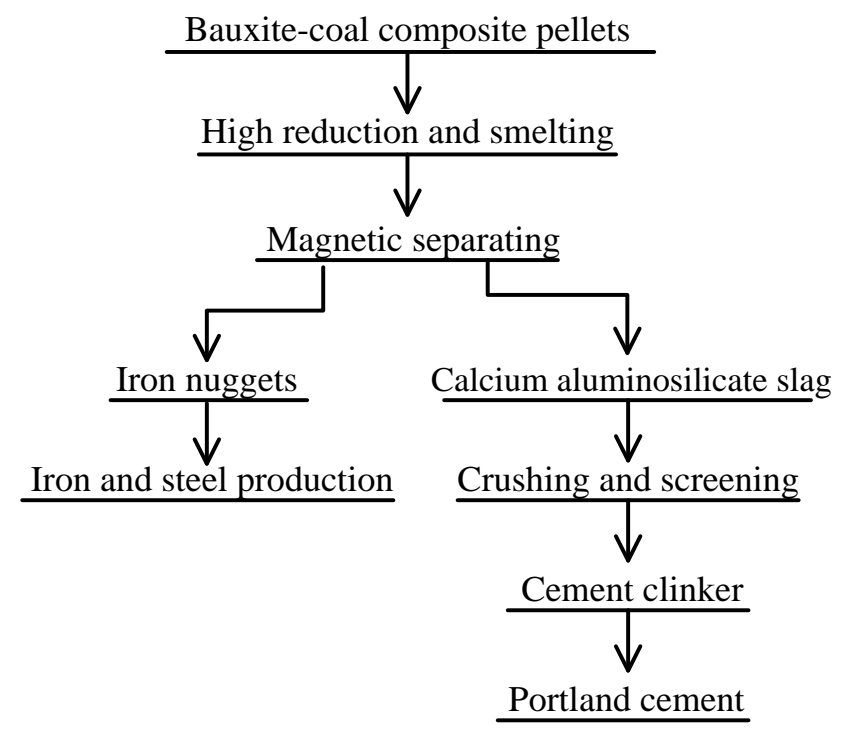

Figure 1. The flow sheet for simultaneously recovering iron and calcium aluminosilicate slag.

Characterization of calcium aluminosilicate slag

The cement clinker of calcium aluminosilicate slag was obtained by crushing, grinding and screening process (see Fig.2). Then it was characterized by using XRD, SEM and EDS to study the phase transformation, morphology and phase composition. The particle size of calcium aluminosilicate slag analysis shows that most of particles are smaller than $120 \mu \mathrm{m}$. All samples were dried and sieved to yield a particle size below $74 \mu \mathrm{m}$ prior to the hydration experiments. The calcium aluminosilicate slag was characterized by using XRD, SEM and EDS to study the phase transformation, morphology and phase composition. 

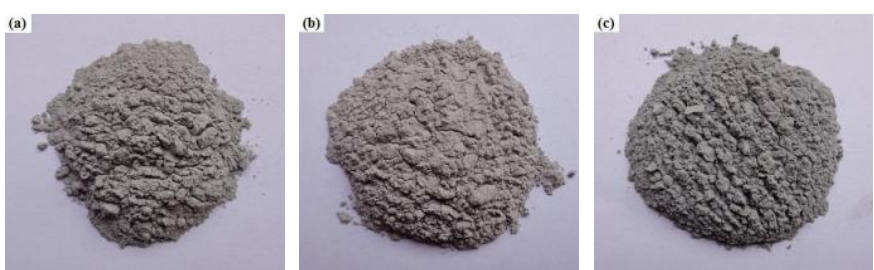

(a) $R=3.60$, (b) $R=3.85$, (c) $R=4.10$

Figure 2. The cement clinker of calcium aluminosilicate slag obtained by crushing and screening.

The chemical compositions of calcium aluminosilicate slag were obtained by XRF and are shown in Table 1. It can be seen that calcium aluminosilicate slag is mainly composed of $\mathrm{Al}_{2} \mathrm{O}_{3}, \mathrm{SiO}_{2}$ and $\mathrm{CaO}$, the content of $\mathrm{Al}_{2} \mathrm{O}_{3}, \mathrm{SiO}_{2}$ and $\mathrm{CaO}$ is $27.21-29.50 \mathrm{wt} \%, 12.69-13.27 \mathrm{wt} \%$ and $49.69-53.83 \mathrm{wt} \%$, respectively.

Table 1. Chemical compositions of calcium aluminosilicate slag with different $w(\mathrm{CaO}) / w\left(\mathrm{SiO}_{2}\right)$

\begin{tabular}{|c|c|c|c|c|c|c|c|}
\hline$w(\mathrm{CaO}) / w\left(\mathrm{SiO}_{2}\right)$ & $\mathrm{FeO}$ & $\mathrm{Al}_{2} \mathrm{O}_{3}$ & $\mathrm{SiO}_{2}$ & $\mathrm{CaO}$ & $\mathrm{MnO}$ & $\mathrm{TiO}_{2}$ & $\mathrm{MgO}$ \\
\hline 3.60 & 3.6 & 29.5 & $\begin{array}{c}13.6 \\
8\end{array}$ & 49.26 & 1.34 & 1.81 & 0.81 \\
\hline 3.85 & 1.24 & 28.7 & $\begin{array}{c}13.2 \\
9\end{array}$ & 51.16 & 2.36 & 2.42 & 0.83 \\
\hline 4.10 & 1.33 & 28.11 & $\begin{array}{c}13.0 \\
4\end{array}$ & 53.48 & 1.35 & 1.83 & 0.86 \\
\hline
\end{tabular}

The effects of $w(\mathrm{CaO}) / w\left(\mathrm{SiO}_{2}\right)$ ratio on the phase formation of the calcium aluminosilicate slag are shown in Fig. 3. It can be seen that the calcium aluminosilicate slag is mainly composed of calcium silicate, calcium aluminate and gehlenite, with the increase of $w(\mathrm{CaO}) / w\left(\mathrm{SiO}_{2}\right)$ ratio, the content of gehlenite decreased gradually. When the $w(\mathrm{CaO}) / w\left(\mathrm{SiO}_{2}\right)$ ratio is 3.60 and 4.10 , the $\beta$-dicalcium silicate $\left(\beta-\mathrm{Ca}_{2} \mathrm{SiO}_{4}, \beta-\mathrm{C}_{2} \mathrm{~S}\right)$, dodecacalcium heptaluminate $\left(12 \mathrm{CaO} \cdot 7 \mathrm{Al}_{2} \mathrm{O}_{3}, \mathrm{C}_{12} \mathrm{~A}_{7}\right)$ and tricalcium aluminate $\left(\mathrm{Ca}_{3} \mathrm{Al}_{2} \mathrm{O}_{6}, \mathrm{C}_{3} \mathrm{~A}\right)$ are the major phases in the calcium aluminosilicate slag, monocalcium aluminate $\left(\mathrm{CaAl}_{2} \mathrm{O}_{4}, \mathrm{CA}\right)$ and gehlenite $\left(\mathrm{Ca}_{2} \mathrm{Al}\left(\mathrm{Al}, \mathrm{Si}_{2} \mathrm{O}_{7}, \mathrm{C}_{2} \mathrm{AS}\right)\right.$ are minor accessories. The phase composition of calcium aluminosilicate slag is listed in Table 2.

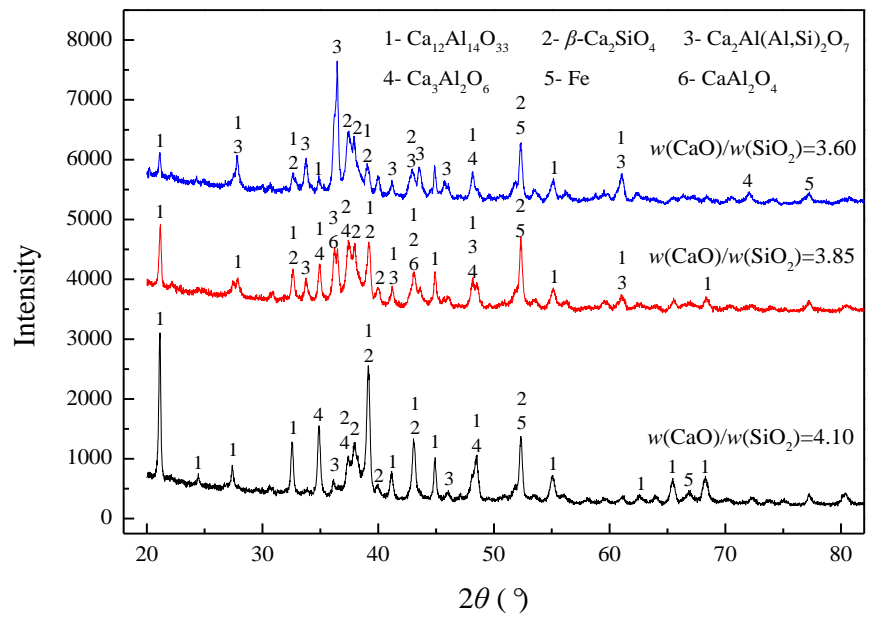

Figure 3. XRD spectrums of calcium aluminosilicate slag with different $w(\mathrm{CaO}) / w\left(\mathrm{SiO}_{2}\right)$. 
Table 2. Mineral components of calcium aluminosilicate slag with different $\mathrm{w}(\mathrm{CaO}) / \mathrm{w}\left(\mathrm{SiO}_{2}\right)$

\begin{tabular}{ccccccc}
\hline$w(\mathrm{CaO}) / w\left(\mathrm{SiO}_{2}\right)$ & $\beta \mathrm{C}_{2} \mathrm{~S}$ & $\mathrm{C}_{12} \mathrm{~A}_{7}$ & $\mathrm{C}_{2} \mathrm{AS}$ & $\mathrm{CA}$ & $\mathrm{C}_{3} \mathrm{~A}$ & $\mathrm{Fe}$ \\
\hline 3.60 & 26.92 & 36.54 & 32.43 & - & 1.29 & 2.82 \\
3.85 & 35.35 & 44.44 & 10.27 & 5.37 & 3.53 & 1.04 \\
4.10 & 25.36 & 56.79 & 4.87 & & 7.02 & 1.09 \\
\hline
\end{tabular}

Hydration mechanism of calcium aluminosilicate slag

The calcium aluminosilicate slag clinkers is mainly composed of $\beta-\mathrm{C}_{2} \mathrm{~S}, \mathrm{C}_{12} \mathrm{~A}_{7}, \mathrm{C}_{2} \mathrm{AS}, \mathrm{CA}, \mathrm{C}_{3} \mathrm{~A}$ and Fe. The $\mathrm{C}_{12} \mathrm{~A}_{7}$ and $\mathrm{C}_{3} \mathrm{~A}$ hydration kinetics are quickly, $\mathrm{CA}$ hydration kinetics is relatively slowly, $\mathrm{C}_{2} \mathrm{AS}$ does not react with water at room temperature, and $\beta-\mathrm{C}_{2} \mathrm{~S}$ phase is hydraulically inactive at early ages. Therefore, all of the hydration reactions are approximately summarized by the following equations (Chotard et al. 2003, Gu et al. 1997, Yang et al. 1984 \& Singh 2006):

$$
\begin{aligned}
& \mathrm{CA}+10 \mathrm{H} \rightarrow \mathrm{CAH}_{10} \\
& 2 \mathrm{CA}+11 \mathrm{H} \rightarrow \mathrm{C}_{2} \mathrm{AH}_{8}+\mathrm{AH}_{3} \\
& 3 \mathrm{CA}+12 \mathrm{H} \rightarrow \mathrm{C}_{3} \mathrm{AH}_{6}+\mathrm{AH}_{3}\left(\mathrm{~T}>30^{\circ} \mathrm{C}\right) \\
& 2 \mathrm{C}_{3} \mathrm{~A}+27 \mathrm{H} \rightarrow \mathrm{C}_{4} \mathrm{AH}_{19}+\mathrm{C}_{2} \mathrm{AH}_{8} \\
& \mathrm{C}_{3} \mathrm{~A}+\mathrm{CH}+12 \mathrm{H} \rightarrow \mathrm{C}_{3} \mathrm{AH}_{13} \\
& 2 \mathrm{C}_{2} \mathrm{~S}+4 \mathrm{H} \rightarrow \mathrm{C}_{3} \mathrm{~S}_{2} \mathrm{H}_{3}+\mathrm{CH} \\
& 2 \beta-\mathrm{C}_{2} \mathrm{~S}+5 \mathrm{H} \rightarrow \mathrm{C}_{3} \mathrm{~S}_{2} \mathrm{H}_{4}+\mathrm{CH} \\
& \mathrm{C}_{12} \mathrm{~A}_{7}+53 \mathrm{H} \rightarrow 6 \mathrm{C}_{2} \mathrm{AH}_{8}+\mathrm{AH}_{3}+2 \mathrm{CH} \\
& \mathrm{C}_{12} \mathrm{~A}_{7}+51 \mathrm{H} \rightarrow 6 \mathrm{C}_{2} \mathrm{AH}_{8}+\mathrm{AH}_{3} \\
& \mathrm{C}_{12} \mathrm{~A}_{7}+33 \mathrm{H} \rightarrow 4 \mathrm{C}_{3} \mathrm{AH}_{6}+3 \mathrm{AH}_{3} \quad\left(\mathrm{~T}>30^{\circ} \mathrm{C}\right)
\end{aligned}
$$

Cement nomenclature is used: $\mathrm{C}=\mathrm{CaO}, \mathrm{A}=\mathrm{Al}_{2} \mathrm{O}_{3}, \mathrm{~S}=\mathrm{SiO}_{2}, \mathrm{H}=\mathrm{H}_{2} \mathrm{O}, \mathrm{CH}=\mathrm{Ca}(\mathrm{OH})_{2}, \mathrm{AH}_{3}=\mathrm{Al}(\mathrm{OH})_{3}$

\section{RESULTS AND DISCUSSION}

\section{$X$-ray diffraction analysis}

It is apparent that the $w(\mathrm{CaO}) / w\left(\mathrm{SiO}_{2}\right)$ ratio is critical to the hydration mechanisms. In order to investigate the effect of $w(\mathrm{CaO}) / w\left(\mathrm{SiO}_{2}\right)$ ratio on hydration, $\mathrm{X}$-ray diffraction analysis was carried out. Fig. 4 displays the hydratation $\mathrm{X}$-ray patterns of calcium aluminosilicate slag with different $w(\mathrm{CaO}) / w\left(\mathrm{SiO}_{2}\right)$ ratios after 28 days of hydration. It can be seen that the hydration products are mainly composed of killalaite $\left(\mathrm{Ca}_{3.2}\left(\mathrm{H}_{0.6} \mathrm{Si}_{2} \mathrm{O}_{7}\right)(\mathrm{OH})\right)$, calcium silicate hydrate $\left(\mathrm{Ca}_{1.5} \mathrm{SiO}_{3.5} \cdot \mathrm{xH}_{2} \mathrm{O}\right.$, Eq.(7)) and calcium aluminates hydroxid $\left(3 \mathrm{CaO} \cdot \mathrm{Al}_{2} \mathrm{O}_{3} \cdot \mathrm{Ca}(\mathrm{OH})_{2} \cdot 18 \cdot \mathrm{H}_{2} \mathrm{O}\right.$, Eq.(4), $\left.\mathrm{Ca}_{12} \mathrm{Al}_{13.86} \mathrm{Fe}_{0.14}(\mathrm{OH})_{2}\right)$. With the increase of $w(\mathrm{CaO}) / w\left(\mathrm{SiO}_{2}\right)$ ratio, the main observed transformations were the disappear of killalaite and continuous increase of $3 \mathrm{CaO} \cdot \mathrm{Al}_{2} \mathrm{O}_{3} \cdot \mathrm{Ca}(\mathrm{OH})_{2} \cdot 18 \cdot \mathrm{H}_{2} \mathrm{O}\left(\mathrm{C}_{4} \mathrm{AH}_{19}\right)$ and $\mathrm{Ca}_{12} \mathrm{Al}_{13.86} \mathrm{Fe}_{0.14}(\mathrm{OH})_{2}$ amounts as a function of $w(\mathrm{CaO}) / w\left(\mathrm{SiO}_{2}\right)$ ratio. As a consequence, the $\mathrm{C}_{12} \mathrm{~A}_{7}$ and $\mathrm{C}_{3} \mathrm{~A}$ hydration kinetics are relatively quickly, as expected. On the other hand, $\mathrm{C}_{2} \mathrm{AS}$ does not react with water at room temperature, and $\beta-\mathrm{C}_{2} \mathrm{~S}$ phase is hydraulically inactive at early ages. 


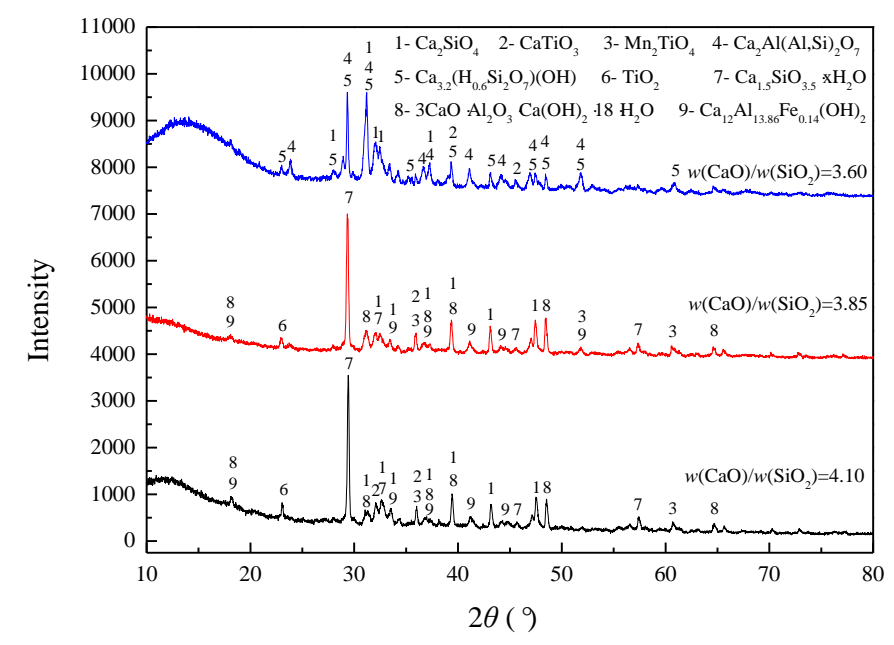

Figure 4. The hydratation XRD patterns of pure $\mathrm{C}_{2} \mathrm{~S}-\mathrm{C}_{12} \mathrm{~A}_{7}$ cement material.

Scanning electron microscopy (SEM) analysis

In order to investigate the effect of $w(\mathrm{CaO}) / w\left(\mathrm{SiO}_{2}\right)$ ratio on hydration microstructure of calcium aluminosilicate slags which were made 28 days after the addition of water. The hydration samples with different $w(\mathrm{CaO}) / w\left(\mathrm{SiO}_{2}\right)$ ratios were analyzed by $\mathrm{SEM}$ and combined the results from the XRD analysis. The SEM photomicrographs and EDS results are displayed in Fig. 5 and Table. 4, respectively. It can be seen that, small crystals are formed in the nanorange with $(2-8 \mu \mathrm{m})$ different shapes and particle sizes distribution which indicate the formation of heterogeneous materials. This is due to the fast reaction of $\mathrm{C}_{3} \mathrm{~A}$ and $\mathrm{C}_{12} \mathrm{~A}_{7}$ with water at early ages of hydration and their very exothermic hydration characteristic. So the formation of stable hydrates occurs sooner $\left(3 \mathrm{CaO} \cdot \mathrm{Al}_{2} \mathrm{O}_{3} \cdot \mathrm{Ca}(\mathrm{OH})_{2} \cdot 18 \cdot \mathrm{H}_{2} \mathrm{O}, \mathrm{Ca}_{12} \mathrm{Al}_{13.86}\right.$

$\left.\mathrm{Fe}_{0.14}(\mathrm{OH})_{2}\right)$. Although $\beta-\mathrm{C}_{2} \mathrm{~S}$ is known to react slowly with water in the early stages of hydration, the presence of $\mathrm{C}_{12} \mathrm{~A}_{7}$ activates $\beta-\mathrm{C}_{2} \mathrm{~S}$ and makes it react relatively faster with water than it would do alone. The hydration products of $\beta$ - $\mathrm{C}_{2} \mathrm{~S}$ are mainly composed of calcium silicate hydrate $\left(\mathrm{Ca}_{1.5} \mathrm{SiO}_{3.5} \cdot x \mathrm{H}_{2} \mathrm{O}, \mathrm{C}-\right.$ $\mathrm{S}-\mathrm{H})$ and $\mathrm{Ca}(\mathrm{OH})_{2}$.

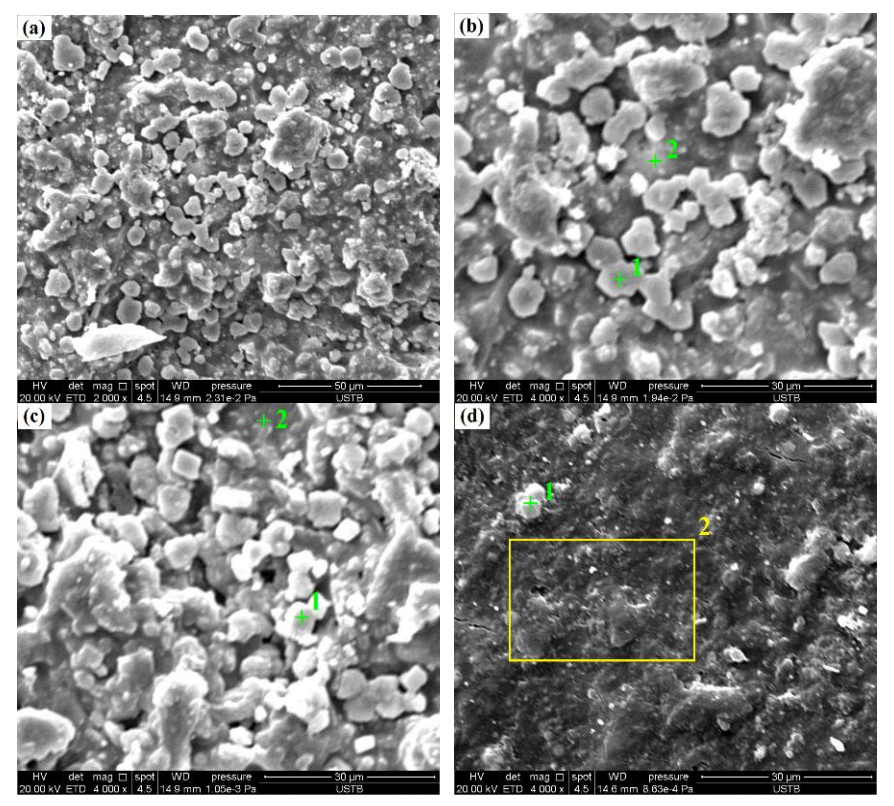



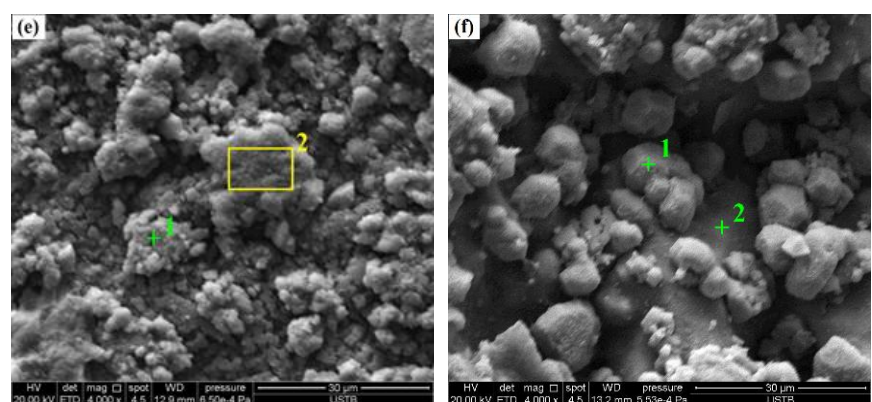

(a) \&(b) $w(\mathrm{CaO}) / w\left(\mathrm{SiO}_{2}\right)=3.60,(\mathrm{c}) \&(\mathrm{~d}) w(\mathrm{CaO}) / w\left(\mathrm{SiO}_{2}\right)=3.85, \quad$ (e) $\&(\mathrm{f}) w(\mathrm{CaO}) / w\left(\mathrm{SiO}_{2}\right)=4.10$ Figure 5. Effects of $w(\mathrm{CaO}) / w\left(\mathrm{SiO}_{2}\right)$ ratios on hydration microstructure.

Table 4. Analysis results of SEM-EDS

\begin{tabular}{cccccccc}
\hline \multirow{2}{*}{ Test positions } & \multicolumn{9}{c}{ Analysis results (at\%) } & \multirow{2}{*}{ Hydration phase } \\
\cline { 2 - 6 } & \multicolumn{1}{c}{$\mathrm{C}$} & $\mathrm{Si}$ & $\mathrm{Al}$ & $\mathrm{Ca}$ & $\mathrm{O}$ & $\mathrm{Sc}$ & \\
\hline Fig.5 (b)-Spot 1 & $16.53(2.57 \mathrm{wt} \%)$ & - & - & 26.42 & 56.88 & 0.17 & $\mathrm{CH}$ \\
Fig.5 (b)-Spot 2 & $31.53(3.99 \mathrm{wt} \%)$ & 4.42 & 5.03 & 14.20 & 44.54 & - & $\mathrm{C}_{2} \mathrm{AS}+\mathrm{CH}$ \\
Fig.5 (c)-Spot 1 & $27.51(4.59 \mathrm{wt} \%)$ & - & 0.04 & 11.03 & 61.27 & - & $\mathrm{C}_{4} \mathrm{AH}_{19}+$ \\
Fig.5 (c)-Spot 2 & - & 3.84 & - & 35.45 & 60.11 & - & $\mathrm{C}_{2} \mathrm{AH}_{8}$ \\
CSH + CH \\
Fig.5 (d)-Spot 1 & $18.31(2.67 \mathrm{wt} \%)$ & - & 0.04 & 14.35 & 65.49 & - & $\mathrm{C}_{4} \mathrm{AH}_{19}+$ \\
Fig.5 (d)-Area 2 & $30.03(4.59 \mathrm{wt} \%)$ & 1.72 & 9.2 & 16.68 & 42.30 & 0.07 & $\mathrm{C}_{2} \mathrm{AH}_{3} \mathrm{AH}_{6}+3 \mathrm{AH}_{3}$ \\
Fig.5 (e)-Spot 1 & $37.36(3.09 \mathrm{wt} \%)$ & - & 1.09 & 12.03 & 49.52 & - & $\mathrm{C}_{3} \mathrm{AH}_{6}+3 \mathrm{AH}_{3}$ \\
Fig.5 (e)-Area 2 & $16.39(2.54 \mathrm{wt} \%)$ & - & - & 26.33 & 56.79 & 0.15 & $\mathrm{CH}$ \\
Fig.5 (f)-Spot 1 & $27.53(4.59 \mathrm{wt} \%)$ & - & 0.05 & 11.08 & 61.25 & - & $\mathrm{C}_{4} \mathrm{AH}_{19}+$ \\
Fig.5 (f)-Spot 2 & $30.44(7.17 \mathrm{wt} \%)$ & - & 7.59 & 3.37 & 56.56 & - & $\mathrm{C}_{2} \mathrm{AH}_{8}$ \\
\hline
\end{tabular}

\section{CONCLUSIONS}

The calcium aluminosilicate slag cement clinker was prepared from bauxite-coal composite pellets by high temperature reduction and smelting process. The hydration results show that, after hydration for 28 days, the hydration products of calcium aluminosilicate slag are mainly composed of killalaite $\left(\mathrm{Ca}_{3.2}\left(\mathrm{H}_{0.6} \mathrm{Si}_{2} \mathrm{O}_{7}\right)(\mathrm{OH})\right)$, calcium silicate hydrate $\left(\mathrm{Ca}_{1.5} \mathrm{SiO}_{3.5} \cdot \mathrm{xH}_{2} \mathrm{O}\right)$ and calcium aluminates hydroxid $\left(3 \mathrm{CaO} \cdot \mathrm{Al}_{2} \mathrm{O}_{3} \cdot \mathrm{Ca}(\mathrm{OH})_{2} \cdot 18 \cdot \mathrm{H}_{2} \mathrm{O}, \mathrm{Ca}_{12} \mathrm{Al}_{13.86} \mathrm{Fe}_{0.14}(\mathrm{O}\right.$

$\mathrm{H})_{2}$ ). With the increase of $w(\mathrm{CaO}) / w\left(\mathrm{SiO}_{2}\right)$ ratio, the killalaite disappeared, the $3 \mathrm{CaO} \cdot \mathrm{Al}_{2} \mathrm{O}_{3} \cdot \mathrm{Ca}(\mathrm{OH})_{2} \cdot 18$.

$\mathrm{H}_{2} \mathrm{O}$ and $\mathrm{Ca}_{12} \mathrm{Al}_{13.86} \mathrm{Fe}_{0.14}(\mathrm{OH})_{2}$ amounts were increased gradually as a function of $\mathrm{w}(\mathrm{CaO}) / \mathrm{w}\left(\mathrm{SiO}_{2}\right)$ ratio. Because the fast reaction of $\mathrm{C}_{3} \mathrm{~A}$ and $\mathrm{C}_{12} \mathrm{~A}_{7}$ with water at early ages of hydration and their very exothermic hydration characteristic, the hydration activity of $\beta-\mathrm{C}_{2} \mathrm{~S}$ was activated and makes it react relatively faster with water than it would do alone. Therefore, the calcium aluminosilicate slag cement clinker has a higher reactivity during the early stage of the hydration process.

\section{ACKNOWLEDGMENTS}

This work was supported by Special Fund for Basic Scientific Research in Colleges and Universities of the Central Business (0903005203413).

\section{REFERENCES}

1) Liu, X.F. Wang, Q.F. Zhang, Q.Z. 2012, Mineralogical characteristics of the super large quaternary bauxite deposits in Jingxi and Debao counties, Western Guangxi, China. Journal of Asian Earth Sciences 52(3): 53-62. 
2) Wang, R.H. Li, M. Chen, D.X. 2011. Resource potential prediction for lateritic high-iron gibbsite bauxite deposits in Guangxi. Geological Bulletin of China 30(8): 1303-1311.

3) Wang, Q.F. Deng, J. Liu, X.F. 2010. Discovery of the REE Minerals and its geological significance in the Quyang Bauxite Deposit, West Guangxi, China. Journal of Asian Earth Sciences 39(6): 701-712.

4) Liu, X.F. Wang, Q.F. Deng, J. Zhang, Q.Z. Sun, S.L. Meng, J.Y. 2010, Mineralogical and geochemical investigations of the Dajia Salento-type bauxite deposits, western Guangxi, China. Journal of Geochemical Exploration 105(3): 137-152.

5) Zhang, Y.Y. Hu, P. Zhang, Z.Y. Qi Y.H. Zou, Z.S. 2014, Mineralogical and geochemical of the guigang Salento-Type bauxite deposits, western guangxi, China. Acta Geodynamica Et Geomaterialia 105(3): 1-7.

6) Kapure, G.U. Rao, C.B. Tathavadkar, V.D. Sen, R. 2011, Direct reduction of low grade chromite overburden for recovery of metals. Ironmaking \& Steelmaking 38(38): 590-596.

7) Guo, Y.H. Gao, J.J. Xu, H.J. Shi, X.F. 2013, Nuggets Production by Direct Reduction of High Iron Red Mud. Journal of Iron \& Steel Research International 20(5): 24-27.

8) Zhang, Y.Y. Qi, Y.H. Shi, X.F. 2015, Reduction and Melting Behavior of Carbon Composite Lateritic Bauxite Pellets. International Journal of Minerals, Metallurgy, and Materials 22(4): 381-388.

9) Zhang, Y.Y. Shi, X.F. Qi Y.H. Zou, Z.S. 2015, Slag composition mechanism based reduction and smelting of carbon composite bauxite pellets. Iron and Steel 50(2): 17-21

10) Zawrah, M.F. Shehata, A.B. Mahmoud, Kishar, E.A. Yamani, R.N. 2011, Synthesis, hydration and sintering of calcium aluminate nanopowder for advanced applications. Comptes Rendus Chimie 14(6): 611-618.

11) David, T.M. Lucia, F.C. Sagrario, M.R. 2013, Hydration of calcium aluminates and calcium sulfoaluminate studied by Raman spectroscopy. Cement \& Concrete Research 47(5): 43-50

12) Touzo, B. Glotter, A. Scrivener, K.L. Mineralogical composition of fondu revisited, in: R.J. Mangabhai,

F.P. Glasser (Eds.), [in] Calcium Aluminate Cements 2001, IOM Communications, London, 2001: 129-134.

13) Bensted, J. 2002, Calcium aluminate cements, [in] J. Bensted, P. Barnes (Eds.), Structure and Performance of Cements, 2nd ed., Spon Press, London: 114-116.

14) Zhen, G.Y Lu, X.Q. Cheng, B.H. Chen, Yan X.F. Zhao, Y.C. 2012, Hydration process of the aluminate $12 \mathrm{CaO} \cdot 7 \mathrm{Al}_{2} \mathrm{O}_{3}$ assisted Portland cement based solidification/stabilization of sewage sludge. Construction \& Building Materials 30: 675-681

15) Luz, A.P. Pandolfelli, V.C. 2011, Halting the calcium aluminate cement hydration process. Ceramics International 37(8): 3789-3793

16) Pacewska, B. Nowacka, M. Aleknevičius, M. Antonvič, V. 2013, Early Hydration of Calcium Aluminate Cement Blended with Spent FCC Catalyst at Two Temperatures, Procedia Engineering 57(1): 844-850.

17) Chotard, T.J. Smith, A. Boncoeur, M.P. 2003, Characterisation of early stage calcium aluminate cement hydration by combination of non-destructive techniques: acoustic emission and X-ray tomography. Journal of the European Ceramic Society 23(13): 2211-2223.

18) Gu, P. Beaudoin, J.J. Quinn, E.G. Robert, E. 1997, Early Strength Development and Hydration of Ordinary Portland Cement/Calcium Aluminate Cement Pastes, Advanced Cement Based Materials 6(2): 53-58.

19) Yang N.R. Zhong, B.Q. 1984, Ettringite formation and conditions for its stability, Journal of the Chinese Ceramic Society 12: 155-159.

20) Singh, N.B. 2006, Hydrothermal synthesis of $\beta$-dicalcium silicate $\left(\beta-\mathrm{Ca}_{2} \mathrm{SiO}_{4}\right)$. Progress in Crystal Growth \& Characterization of Materials 52(1-2): 77-83. 